\title{
PENGARUH PEMBERIAN EKSTRAK DAUN KELOR (Moringa oleifera) TERHADAP KADAR HEMOGLOBIN PADA TIKUS PUTIH (Rattus norvegicus) GALUR WISTAR JANTAN
}

\author{
Yesi Nurmalasari', Rakhmi Rafie ${ }^{2}$, Efrida Warganegara³, Lingga Desta \\ Wahyuni ${ }^{4}$
}

${ }^{1}$ Departemen Gizi Medik Fakultas Kedokteran Universitas Malahayati

${ }^{2}$ Departemen Anatomi Fakultas Kedokteran Universitas Malahayati

${ }^{3}$ Departemen Mikrobiologi Fakultas Kedokteran Universitas Lampung

${ }^{4}$ Program Studi Kedokteran Fakultas Kedokteran Universitas Malahayati

[email korespondensi: linggadestawahyuni69@gmail.com]

\begin{abstract}
The Effect of Giving Moringa oleifera Leaves on Hemoglobin Levels in White Rats (Rattus norvegicus) Male Wistar. Hemoglobin is a tetrameric erythrocyte protein composed of globin and heme proteins. Free radicals can cause lysis of the erythrocyte membrane. This process can be prevented by administering antioxidants. Moringa leaves are included as natural antioxidants that have neurofective properties through an antioxidative mechanism. To determine the effect of extracts of the leaves of Moringa (Moringa oleifera)terhadap hemoglobin levels in rats (Rattus norvegicus) Wistar male. This type of pure experimental research (tue-experiment) used pre and post control group design. Samples were white mice (Rattus norvegicus) strain Wistar maleaged 1-4 weeks weighing 100-150 grams, totaling 28 tails. The sample was divided into four groups including the pure group (KM) the group that was not given Moringa leaf extract, the 1st treatment group (KP1) the group that was given the moringa leaf extract at a dose of $150 \mathrm{mg} / \mathrm{kgBB}$, the 2nd treatment group (KP2) the group that was given the moringa leaf extract dose of $450 \mathrm{mg} / \mathrm{kg}$ body weight, and the positive group $(\mathrm{KP})$ in the group given vitamin supplements at a dose of $5.4 \mathrm{ml} / \mathrm{kg}$. Test Paired ttest showed no significant difference $(p>0.05)$ in Kelompok Pure $(K M) p=0.155$, treatment Group 1 (KP1) $p=0.329$, treatment group $2(K P 2) p=0.014$ and Kelompok Positive (KP) $p=0.012$. The Kruskal-Wallis test showed $p=0.027(p>$ $0.05)$, meaning there was no significant difference between groups, the test Post Hoc using Mann-Whitney showed a statistically significant difference $(p<0.05)$ in Treatment Group 2 (KP2 ) with a value of $p=0.002$, and the Positive Group (KP) with a value of $p=0.002$. There is the effect of extracts of the leaves of Moringa (Moringa oleifera) on the hemoglobin levels of white rats (Rattus norvegicus) Wistar strain male in the treatment group $2(\mathrm{KP} 2)$ dose of $450 \mathrm{mg} / \mathrm{kg}$ and Kelompok Positif (KP) dose of $5.4 \mathrm{ml} / \mathrm{kgBB}$.
\end{abstract}

Keywords: Moringa leaves, Anemia, Hemoglobin.

\begin{abstract}
Abstrak: Pengaruh Pemberian Ekstrak Daun Kelor (Moringa oleifera) Terhadap Kadar Hemoglobin Pada Tikus Putih (Rattus norvegicus) Galur Wistar Jantan. Hemoglobin merupakan suatu protein tetrametrik eritrosit yang tersusun dari protein globin dan heme. Radikal bebas dapat menyebabkan lisisnya membran eritrosit. Proses tersebut dapat dicegah dengan pemberian antioksidan. Daun kelor termasuk dalam antioksidan alami yang memiliki sifat neurofektif melalui mekanisme antioksidatif. Mengetahui pengaruh pemberian ekstrak daun kelor (Moringa oleifera) Terhadap kadar hemoglobin pada tikus putih (Rattus norvegicus) galur Wistar jantan. Jenis penelitian eksperimental murni (true experiment) menggunakan pre and post with control group design. Sampel adalah tikus putih (Rattus norvegicus) galur Wistar jantan berusia 1-4 minggu dengan berat 100-150-gram sejumlah 28 ekor. Sampel dibagi empat kelompok meliputi Kelompok murni (KM) kelompok yang tidak diberikan ekstrak daun kelor, Kelompok Perlakuan 1 (KP1) kelompok yang diberi ekstrak daun kelor dosis $150 \mathrm{mg} / \mathrm{kgBB}$, Kelompok Perlakuan 2 (KP2) kelompok yang diberi ekstrak daun kelor dosis 450
\end{abstract}


$\mathrm{mg} / \mathrm{kgBB}$ dan Kelompok Positif (KP) kelompok yang diberikan suplemen vitamin dosis $5,4 \mathrm{ml} / \mathrm{kgBB}$. Uji Paired T-test menunjukkan tidak ada perbedaan yang bermakna $(p>0,05)$ pada Kelompok Murni (KM) $p=0,155$, Kelompok Perlakuan 1(KP1) $p=0,329$, Kelompok Perlakuan 2(KP2) $p=0,014$ dan Kelompok Positif (KP) $p=0,012$. Uji Kruskal-Wallis didapatkan $p=0,027(p>0,05)$ berarti tidak terdapat perbedaan bermakna antar kelompok, uji Post Hoc dengan menggunakan Mannwhitney menunjukkan adanya perbedaan bermakna secara statistik $(\mathrm{p}<0,05)$ pada Kelompok Perlakuan 2 (KP2) dengan nilai $p=0,002$, dan Kelompok Positif (KP) dengan nilai $p=0,002$. Terdapat pengaruh pemberian ekstrak daun kelor (Moringa oleifera) terhadap kadar hemoglobin tikus putih (Rattus norvegicus) Galur wistar jantan pada kelompok perlakuan 2 (KP2) dosis $450 \mathrm{mg} / \mathrm{kgBB}$ dan Kelompok Positif (KP) dosis $5,4 \mathrm{ml} / \mathrm{kgBB}$.

Kata Kunci: Daun kelor, Anemia, Hemoglobin

\section{PENDAHULUAN}

Hemoglobin merupakan suatu protein tetrametrik eritrosit yang tersusun dari protein globin dan heme. Hemoglobin ini memiliki fungsi yang penting dalam tubuh manusia yaitu dapat mengangkut oksigen ke jaringan dan mengangkut karbondioksida dari jaringan perifer ke organ respirasi, apabila terjadi penurunan kadar hemoglobin dalam darah sampai berada dalam batas normal, maka tubuh tidak dapat bekerja dengan maksimal, sehingga dapat mengakibatkan terjadinya anemia (Indriani, 2019).

Anemia merupakan salah satu masalah kesehatan utama yang sering dijumpai di dunia dan kesehatan yang telah menyerang lebih dari 600 juta manusia. Anemia itu sendiri merupakan suatu keadaan dimana komponen darah dalam jumlah tidak stabil, sehingga terjadi penurunan pada produksi sel darah merah sampai memiliki nilai kadar dibawah rentan normal $13,5 \mathrm{~g} / \mathrm{dL}$ (pria), 11,5 g/dL dan $11.0 \mathrm{~g} / \mathrm{dL}$ (anakanak) (Kurniawati, 2019).

\section{Berdasarkan World}

Health

Organization

(WHO)

(2015)

menyebutkan bahwa prevalensi anemia di negara maju adalah sekitar $14 \%$ dan $51 \%$ di negara berkembang. Prevalensi anemia di Indonesia pada tahun 2013 menurut kelompok usia 1-5 tahun yaitu sebesar 28,1\%, usia 5-14 tahun sebesar $26,4 \%$, usia 15-24 tahun sebesar $18,4 \%$ dan usia 25-34 tahun sebesar 16,9\% (Kemenkes RI, 2013). Sehingga dapat kita lihat dari data yang telah dipaparkan di atas, masih banyak sekali kejadian anemia di Indonesia ini, sekarang juga masih menjadi masalah kesehatan lainnya bila tidak ditangani dengan baik, sehingga perlu perhatian serius untuk menangani dan mencegah masalah tersebut (Kumalasari, 2019).

Salah satu upaya yang dapat dilakukan untuk penderita anemia ini dapat memenuhi kebutuhan asupan gizi dan suplemen vitamin sangobion, yaitu dengan mengkonsumsi sayuran yang memiliki kandungan zat besi yang baik, yang dapat dijumpai pada sayursayuran lainnya, seperti bayam, sawi, katuk, dan kangkung (Suhada dkk, 2019).

Adapun nilai kandungan dari jenis sayuran tersebut, memiliki nilai kandungan zat besi seperti bayam yaitu sebanyak 3,9 mg, sawi 2,9 mg, katuk 2,7 mg, dan kangkung 2,5 mg. Selain dari jenis sayuran-sayuran tersebut, ada juga sayuran jenis lainnya yang paling tinggi akan kandungan zat besi nya, dan memiliki khasiat yang baik untuk mencegah anemia tersebut, sehingga dapat dijadikan potensi untuk pembentukan hemoglobin dalam darah. Salah satu tanaman dan bahan pangan yang berpotensi untuk dijadikan sebagai makanan pembawa dalam upaya fortifikasi zat besi di Indonesia yaitu salah satunya pada daun kelor (Suhada dkk, 2019).

Daun kelor (Moringa oleifera) merupakan salah satu tanaman lokal yang dapat dikenal berabad-abad, juga sebagai tanaman multiguna, padat nutrisi serta berkhasiat obat. Senyawa alami ini mengandung lebih banyak dan beragam dibandingkan jenis tanaman lainnya yang ada. Tanaman kelor ini mengandung zat besi lebih tinggi dari pada sayuran lainnya yaitu sebesar 28,2 
mg, serta nutrisi yang cukup tinggi, mengatasi kekurangan nutrisi dan mengandung 46 antioksidan kuat yang dapat melindungi tubuh dari radikal bebas serta memiliki banyak manfaat bagi manusia (Mursito dkk, 2020).

$$
\text { Daun kelor mengandung }
$$

kandungan asam askorbat, fenolat dan flavonoid. Flavonoid ini menyebabkan daun kelor ini dapat digunakan sebagai sumber bahan alami antioksidan. Antioksidan merupakan senyawa alami yang dapat menyumbangkan satu atau lebih elektron pada radikal bebas, sehingga radikal bebas dapat mengurangi efek tersebut. Daun kelor juga mengandung dua jenis zat bioaktif yaitu kaempferol dan quercetin. Pada penelitian lain yang dilakukan oleh Wahyuni, dkk (2013) melaporkan bahwa daun kelor juga mengandung zat kimia, seperti emulsion, alkaloid, pahit tidak beracun seperti vitamin A, B1, B2 dan C (Mursito dkk, 2020).

Selain itu daun kelor juga mengandung lebih 90 nutrisi 48 jenis antioksidan 36 senyawa anti inflamasi, sehingga dapat digunakan sebagai obat herbal untuk meningkatkan kadar hemoglobin dalam darah. Adapun kandungan nutrisi penting lainnya seperti zat besi $(\mathrm{Fe})$ memiliki sebanyak 28,2 mg, kalsium (Ca) 2003,0 mg, dan vitamin $\mathrm{A} 16,3 \mathrm{mg}$, kaya-karoten, protein, vitamin $A, C, D, E, K$, dan B (tiamin, riboflavin, niasin, asam pantotenat, biotin, vitamin B6, vitamin B12, dan folat (Mursito dkk, 2020).

Daun kelor ini telah terbukti oleh hasil penelitian dari lembaga dan laboratorium terpercaya, sehingga tidak memiliki efek samping juga baik dikonsumsi oleh anak-anak maupun orang dewasa. Sehingga kandungan kelor yang memiliki peran yang baik dalam meningkatkan pembentukan hemoglobin diantaranya quercetin, zat besi (Fe) dan vitamin C (Winarno, 2018).

Daun kelor (Moringa oleifera) merupakan salah satu bagian tanaman kelor yang telah banyak diteliti kandungan gizi dan kegunaannya. Banyak yang menyebutkan pohon ini sebagai "dinamit gizi" karena jumlah yang berlebih dari nutrisi penting seperti zat besi, kalsium dan vitamin A. Kelor digunakan sebagai bahan utama ratusan obat, baik untuk pencegahan maupun pengobatan. Salah satunya yaitu karena adanya kandungan senyawa novel isothiocyanate, yang merupakan kelas Bioavailabilitas Phytochemicals yang terdapat pada daun kelor (Krisnadi, 2015).

Dunia ilmu pengetahuan mengakui bahwa kelor merupakan tanaman yang paling kaya nutrisi yang ditemukan untuk saat ini. Mengandung banyak dan lebih padat vitamin, mineral, antioksidan kuat tertinggi, asam amino esensial lengkap dan ditambah senyawa lainnya. Tanaman kelor mengandung 46 antioksidan kuat yang melindungi tubuh dari radikal bebas, mengandung 18 asam amino ( 8 diantaranya esensial) yang dibutuhkan tubuh untuk membangun sel-sel baru, 36 senyawa anti inflamasi, serta 90 nutrisi alami seperti vitamin dan mineral (Krisnadi, 2015).

Kelor tidak hanya kaya akan nutrisi akan tetapi juga memiliki sifat fungsional karena tanaman ini mempunyai khasiat dan manfaat buat kesehatan manusia. Baik kandungan nutrisi maupun berbagai zat adiktif yang terkandung dalam tanaman ini dapat dimanfaatkan untuk kepentingan makhluk hidup dan lingkungan. Hal ini disebabkan karena daun kelor mengandung unsur zat gizi mikro yang sangat dibutuhkan oleh penderita anemia, seperti zat besi, kalsium, vitamin C, beta carotine sebagai bahan alternatif untuk meningkatkan status gizi pada anemia. Pada daun kelor juga memiliki fungsi sebagai farmakologis, yaitu antimikroba, antijamur, antihipertensi, antihiperglikemik dan anti-inflamasi (Aminah dkk, 2015).

Kandungan pada quercetin juga bekerja untuk dapat meningkatkan fungsi kapiler tubuh serta dapat meningkatkan kemampuan untuk menyerap vitamin $\mathrm{C}$, adapun pada vitamin $C$ ini juga dapat bekerja untuk membantu pada penyerapan zat besi, apabila pemberian zat besi nya maksimal, maka produksi darah dalam hemoglobin pun akan meningkat. Sedangkan kandungan pada zat besi 
(Fe) yang dapat membantu untuk pembentukan darah dalam produksi hemoglobin serta dapat menyokong sistem kekebalan pada tubuh (Amalia dan Tjiptaningrum, 2016).

\section{METODE}

Rancangan

menggunakan metode penelitian eksperimental murni (true experiment) dengan menggunakan rancangan penelitian pre and post test with control group design. yang menggunakan tikus sebanyak 26 ekor dibagi 4 kelompok secara random sampling, dengan prosedur sebagai berikut:

\section{Persiapan Dan Prosedur Penelitian}

Hewan coba yang digunakan pada penelitian ini adalah Tikus putih (Rattus norvegicus) galur Wistar jantan. Semua hewan coba dipelihara atau diadaptasikan di Laboratorium Terpadu Universitas Malahayati selama 7 hari di dalam kandang dengan suhu ruangan standar pemeliharaan yaitu $\pm 25^{\circ} \mathrm{C}$, dan diberikan pakan standar Comfeed BR-II sebanyak $100 \mathrm{gr} /$ kelompok/hari dan air minum diberikan 2 kali sehari pada pukul 10.00 dan pada pukul 16.00 setiap harinya (Rohilla et al, 2012). Selanjutnya pemberian ekstrak daun kelor selama 14 hari, pada hari ke-7 dimulai dengan pemberian ekstrak daun kelor dengan dosis $150 \mathrm{mg} / \mathrm{kgBB} /$ hari, $450 \mathrm{mg} / \mathrm{kgBB} / \mathrm{hari}$ dan suplemen vitamin dengan dosis $5,4 \mathrm{ml} / \mathrm{kgBB}$ diberikan kelompok Positif, serta 2 jam sebelum pemberian pakan dan diberikan 1 kali sehari, yaitu pada pukul 08.00 WIB. Pemberian ekstrak daun kelor dilakukan dengan menggunakan sonde lambung yang diberikan per oral kepada hewan coba dan pemberian ekstrak daun kelor dilakukan sampai hari ke-14 kepada tiap kelompok perlakuan (Indriani, 2019).

\section{Pemberian Ekstrak Daun Kelor}

Pada hari ke-8, tikus wistar dibagi menjadi 4 kelompok yang masingmasing terdiri dari 9 ekor tikus wistar yang dipilih berdasarkan simple random sampling. Mulai hari ke-8 pada kelompok pertama yaitu kelompok murni, diberikan pakan standar dan aquades tanpa perlakuan apapun. Pada kelompok kedua, tikus wistar diberikan pakan standar dan aquades selama 7 hari dan diberikan ekstrak daun kelor (Moringa oleifera) dosis 150 $\mathrm{mg} / \mathrm{kgBB} /$ hari selama 14 hari. Pada kelompok ketiga, tikus wistar diberikan pakan standar dan aquades selama 7 hari dan diberikan ekstrak daun kelor (Moringa oleifera) dosis 450 $\mathrm{mg} / \mathrm{kgBB} /$ hari selama 14 hari (Setiawan dkk, 2018) dan diberikan suplemen vitamin dengan dosis $5,4 \mathrm{ml} / \mathrm{kgBB} /$ hari selama 14 hari.

\section{Pengambilan Darah Tikus}

Tikus putih pada hewan coba di anastesi terlebih dahulu dan diinjeksikan ketamine dengan dosis $0,2 \mathrm{cc} / 100 \mathrm{grbb}$. Darah tersebut diambil dari ekor dengan menggunakan spuit 3 $\mathrm{ml}$ ditarik perlahan kemudian dimasukkan kedalam tabung EDTA, kemudian sampel darah yang diambil adalah sebanyak $1 \mathrm{cc}$, lalu sampel darah tadi dimasukkan kedalam tabung EDTA dengan berhati-hati, lalu dihomogenkan agar darah tidak beku (Nugroho, 2018).

\section{Pemeriksaan
Hemoglobin Tikus}

Sampel darah yang akan dilakukan pengukuran kadar hemoglobin dengan cara menghomogenkan terlebih dahulu dengan menggunakan Mixer Roller selama 5 menit, sampel darah yang sudah dihomogen, kemudian diperiksa dengan menggunakan alat Auto Hematology Analyzer dengan cara tekan tombol Whole Blood -WBll pada layar, tekan tombol ID dan masukkan no sampel, tekan enter, kemudian tekan bagian atas dari tempat sampel yang berwarna ungu, untuk membuka dan letakkan sampel dalam adaptor, tutup tempat sampel dan tekan-RUNII, sehingga hasil akan muncul pada layar secara otomatis.

\section{Pemberian Perlakuan Pada Tikus}

Pemberian perlakuan pada tikus ini selama 14 hari. Tikus sebanyak 28 ekor dibagi dalam 4 kelompok secara random, Kelompok Murni (KM), 
Kelompok Positif (KP), Kelompok Perlakuan 1 (KP1), dan Kelompok Perlakuan 2 (KP2).

Pemberian perlakuan pada tikus putih adalah sebagai berikut:

a. Kelompok murni (KM) = Kelompok tikus yang tidak diberi ekstrak daun kelor.

b. Kelompok perlakuan 1 (KP1) = Kelompok tikus yang diberi ekstrak daun kelor dengan dosis 150 $\mathrm{mg} / \mathrm{kgBB} /$ hari selama 14 hari.

c. Kelompok perlakuan 2 (KP2) = Kelompok tikus yang diberi ekstrak daun kelor dengan dosis 450 $\mathrm{mg} / \mathrm{kgBB} /$ hari selama 14 hari.

d. Kelompok Positif (KP) = Kelompok tikus yang diberikan suplemen vitamin dengan dosis $5,4 \mathrm{ml} / \mathrm{kgBB}$ selama 14 hari.

\section{Penetapan Kadar Hemoglobin Tikus}

Pengambilan darah dilakukan sebelum dan sesudah diberi ekstrak daun kelor dan suplemen vitamin selama 14 hari, untuk mengetahui apakah ekstrak daun kelor dan suplemen vitamin efektif dapat meningkatkan kadar hemoglobin. Kadar hemoglobin normal pada tikus putih (Rattus norvegicus) dalam darah adalah $11,1-18 \mathrm{~g} / \mathrm{dL}$ (Widyastuti, 2013).

Populasi penelitian ini adalah tikus putih galur wistar jantan yang berusia 1-4 minggu, berat badan 100-150-gram yang sesuai dengan kriteria inklusi. Penelitian ini dilaksanakan mulai November 2020 sampai Januari 2021.

HASIL

Tabel 1. Karakteristik sampel

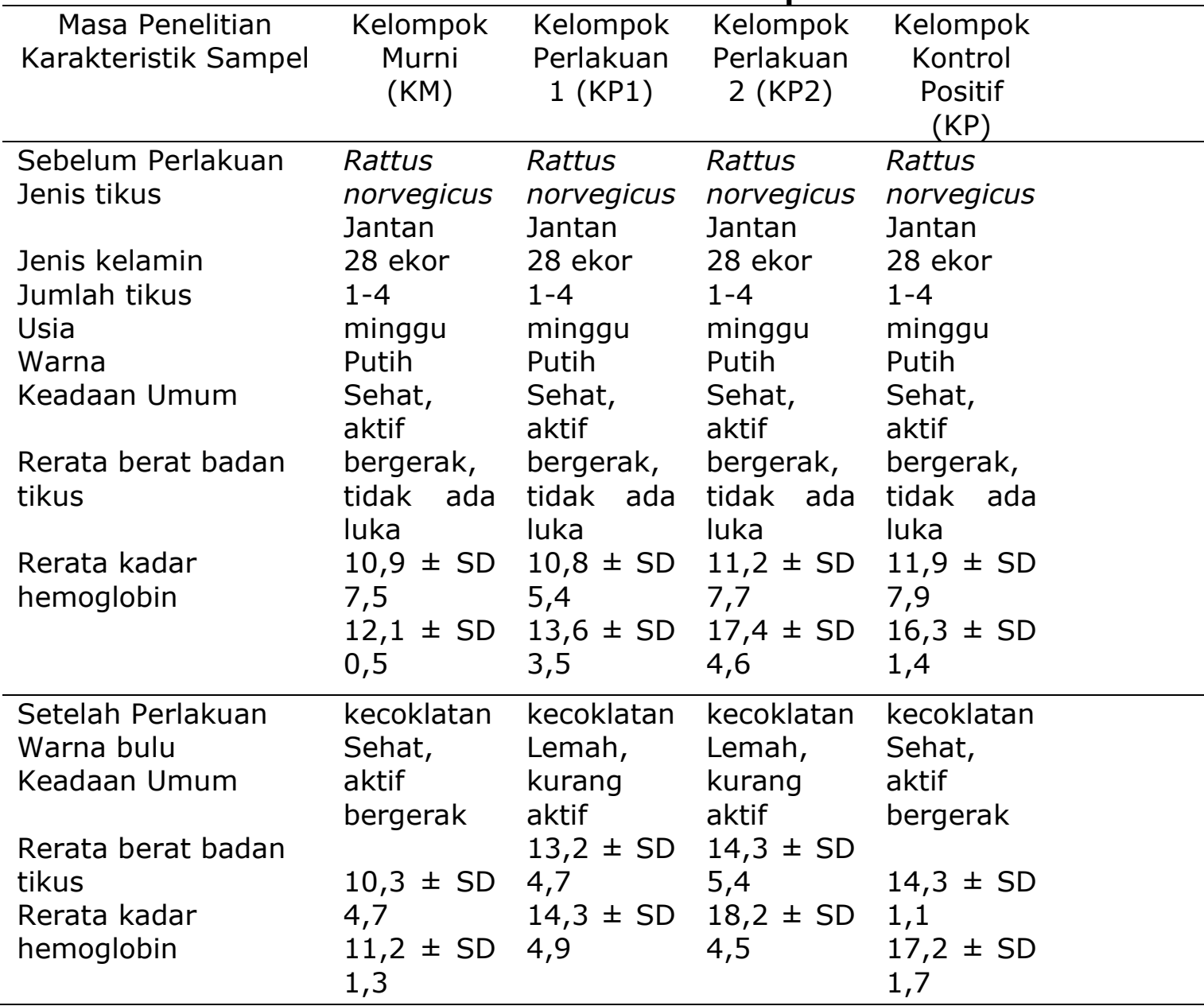

Keterangan:

$\mathrm{KM}$ : tidak diberikan ekstrak daun kelor 
$\mathrm{K} 1$ : diberikan ekstrak daun kelor dengan dosis $150 \mathrm{mg} / \mathrm{kgBB}$

$\mathrm{K} 2$ : diberikan ekstrak daun kelor dengan dosis $450 \mathrm{mg} / \mathrm{kgBB}$.

$\mathrm{KP}$ : diberikan suplemen vitamin dosis $5,4 \mathrm{ml} / \mathrm{kgBB}$.

Tabel 2. Kadar hemoglobin sebelum dan sesudah perlakuan

\begin{tabular}{ccccc}
\hline Kelompok & $\begin{array}{c}\text { Rerata Hb } \\
\text { sebelum } \\
\text { perlakuan } \\
\begin{array}{c}\text { standar } \\
\text { deviasi }\end{array}\end{array}$ & $\begin{array}{c}\text { Median (Min- } \\
\text { maks) } \mathrm{Hb} \\
\text { sebelum } \\
\text { perlakuan }\end{array}$ & $\begin{array}{c}\text { Rerata Hb } \\
\text { setelah } \\
\text { perlakuan } \\
\text { 土standar } \\
\text { deviasi }\end{array}$ & $\begin{array}{c}\text { Median (Min-maks) } \\
\text { Hb setelah } \\
\text { perlakuan }\end{array}$ \\
\hline Kontrol Murni & $12,1 \pm 0,5$ & $\begin{array}{c}11,950(11,5- \\
12,8)\end{array}$ & $11,3 \pm 1,3$ & $\begin{array}{c}(13,8-15,11,350 \\
(9,5-12,8)\end{array}$ \\
\hline $\begin{array}{c}\text { Kelompok } \\
\text { dosis 150 }\end{array}$ & $13,6 \pm 3,5$ & $\begin{array}{c}14,000(9,2- \\
17,2)\end{array}$ & $14,3 \pm 4,9$ & $\begin{array}{c}14,350 \\
(8,8-20,1)\end{array}$ \\
\hline $\begin{array}{c}\text { Kelompok } \\
\text { dosis 450 }\end{array}$ & $17,4 \pm 4,6$ & $\begin{array}{c}19,300(8,2- \\
20,4)\end{array}$ & $18,2 \pm 4,5$ & $\begin{array}{c}19,750 \\
(9,1-20,9)\end{array}$ \\
\hline Kontrol Positif & $11,9 \pm 7,9$ & $16,200(14,7-$ & $17,2 \pm 1,7$ & $\begin{array}{c}16,950 \\
(15,3-19,9)\end{array}$ \\
\hline
\end{tabular}

Berdasarkan tabel 2 di atas diketahui bahwa Hasil uji normalitas ini didapatkan nilai rerata kadar hemoglobin sebelum dan setelah perlakuan, pada kelompok KM memiliki rerata kadar hemoglobin $(12,1 \pm$ SD $0,5)$ dan $(11,2 \pm$ SD1,3) menunjukkan terdapat penurunan kadar hemoglobin, pada kelompok KP rerata kadar hemoglobin $(13,6 \pm$ SD 3,5$)$ dan $(14,3 \pm$ SD 5,4) menunjukkan terdapat peningkatan kadar hemoglobin, pada kelompok KP2 memiliki rerata kadar hemoglobin $(17,4 \pm$ SD 4,6$)$ dan $(18,2 \pm$ SD 4,5) menunjukkan terdapat peningkatan kadar hemoglobin, dan pada kelompok KP memiliki rerata kadar hemoglobin $(16,3 \pm$ SD 1,4$)$ dan $(17,2 \pm$ SD1,7) menunjukkan bahwa terdapat peningkatan kadar hemoglobin dari sebelum dan setelah perlakuan. Sehingga dapat dikatakan bahwa semakin tinggi nilai standar deviasi tersebut maka akan semakin tinggi pula selisih dari nilai rata-rata tersebut.

Tabel 3. Uji normalitas nilai kadar hemoglobin sebelum dan setelah perlakuan

\begin{tabular}{ccc}
\hline Kelompok & $\begin{array}{c}\text { Hasil uji normalitas nilai } \\
\text { Hb sebelum perlakuan }\end{array}$ & $\begin{array}{c}\text { Hasil uji normalitas nilai Hb } \\
\text { setelah perlakuan }\end{array}$ \\
\hline Kontrol Murni & $0,527^{*}$ & $0,689^{*}$ \\
Kelompok dosis 150 & $0,299^{*}$ & $0,384^{*}$ \\
Kelompok dosis 450 & 0,003 & 0,001 \\
Kontrol Positif & $0,525^{*}$ & $0,747^{*}$ \\
\hline
\end{tabular}

(*) terdapat perbedaan bermakna $(p<0,05)$

Berdasarkan tabel di atas diketahui bahwa dari dari uji normalitas dengan shapiro wilk nilai kadar hemoglobin sebelum dan setelah perlakuan menunjukkan data tersebut menunjukkan distribusi normal dengan nilai $p=>0,05$ pada kelompok murni (KM) nilai $p=0,527$ dan $p=0,689$, kelompok perlakuan 1 (KP1) nilai $\mathrm{p}=0,299$ dan $\mathrm{p}=0,384$, dan kelompok positif (KP) nilai $p=0,525$ dan $p=0,747$. 
Tabel 4. Hasil Uji paired t-test perbedaan nilai rerata \pm standar deviasi kadar hemoglobin sebelum dan setelah perlakuan

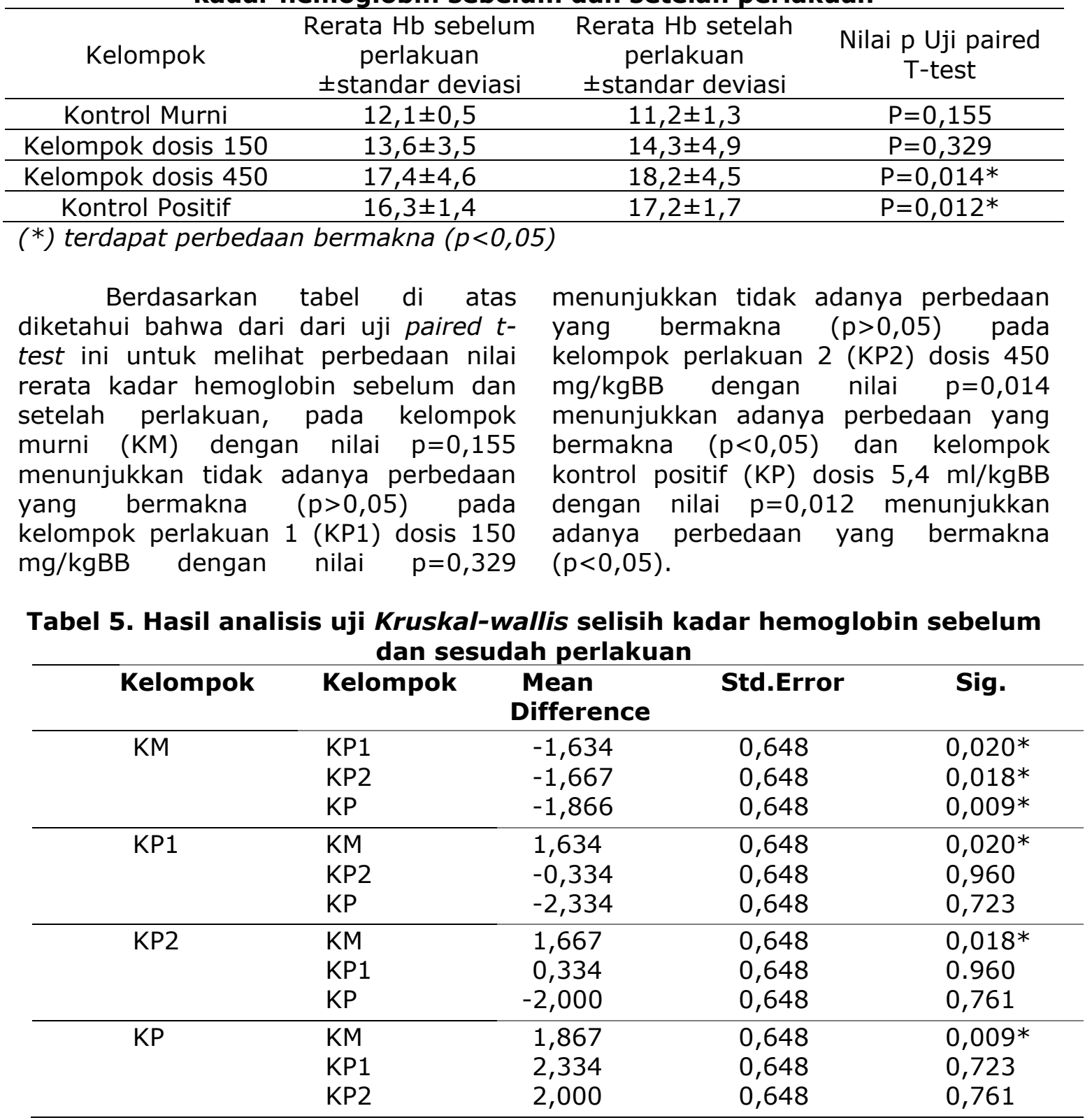

$\left(^{*}\right)$ terdapat perbedaan bermakna $(p<0,05)$

Berdasarkan tabel 5 diatas diketahui bahwa Analisis statistik hasil dari uji kruskal-wallis menunjukkan adanya selisih hb $(p=0,05)$ pada kelompok KM dengan kelompok KP1 $\mathrm{p}=0,020$, kelompok $\mathrm{Km}$ dengan kelompok KP2 $\mathrm{p}=0,018$, kelompok $\mathrm{Km}$ dengan kelompok KP $p=0,009$, kelompok KP1 dengan kelompok KM $\mathrm{p}=0,020$, kelompok KP2 dengan kelompok KM $p=0,018$, dan kelompok $K P$ dengan kelompok KM $p=0,009$. Hal ini menunjukkan bahwa adanya selisih perbedaan yang bermakna antara kelompok. 
Tabel 6. Hasil analisis uji Post Hoc menggunakan Mann-Whitney

\begin{tabular}{ll}
\hline Kelompok & \multicolumn{1}{|c}{} \\
\hline KM vs KP1 & $\mathrm{P}=0,180$ \\
KM vs KP2 & $\mathrm{P}=0,002^{*}$ \\
KM vs KP & $\mathrm{P}=0,002^{*}$ \\
KP1 vs KP2 & $\mathrm{P}=0,937$ \\
KP1 vs KP & $\mathrm{P}=0,818$ \\
KP2 vs KP & $\mathrm{P}=0,589$ \\
\hline
\end{tabular}

$\left(^{*}\right)$ terdapat perbedaan bermakna $(p<0,05)$

\begin{abstract}
Berdasarkan tabel 6 di atas diketahui bahwa Hasil analisis selanjutnya dilakukan dengan post hoc menggunakan Mann-Whitney menunjukan adanya perbedaan yang bermakna $(p<0,05)$ antara kelompok, didapatkan perbedaan bermakna $(p<0,05)$ pada kelompok KM dengan KP2 $(p=0,002)$ dan kelompok KM PEMBAHASAN
\end{abstract}

Berdasarkan tabel 2 dapat disimpulkan bahwa kadar hemoglobin setelah mengkonsumsi ekstrak daun kelor lebih tinggi dari pada kadar hemoglobin sebelum mengkonsumsi ekstrak daun kelor. Pada penelitian ini dilakukan pemberian ekstrak daun kelor selama 14 hari sebagai antioksidan yang dapat meningkatkan kadar hemoglobin pada tikus putih. Hasil penelitian yang dilakukan dapat dianalisis uji normalitas dengan shapiro wilkdidapatkan nilai rerata kadar hemoglobin sebelum dan setelah perlakuan. Pada kelompok KM memiliki rerata kadar hemoglobin $(12,1 \pm \mathrm{SD}$ $0,5)$ dan $(11,2 \pm$ SD1,3) mengalami penurunan kadar hemoglobin, pada kelompok KP1 rerata kadar hemoglobin $(13,6 \pm$ SD 3,5$)$ dan $(14,3 \pm$ SD 5,4) mengalami peningkatan kadar hemoglobin, pada kelompok KP2 memiliki rerata kadar hemoglobin $(17,4 \pm$ SD 4,6$)$ dan $(18,2 \pm$ SD 4,5) mengalami peningkatan kadar hemoglobin, dan pada kelompok KP memiliki rerata kadar hemoglobin $(16,3 \pm$ SD 1,4$)$ dan $(17,2 \pm$ SD1,7) mengalami peningkatan kadar hemoglobin dari sebelum dan setelah perlakuan. Kadar hemoglobin normal pada tikus putih (Rattus norvegicus) yaitu 11,1-18 gr/dl (Widyastuti, 2013). dengan KP $(p=0,002)$ maka dapat dikatakan bahwa ada pengaruh pemberian ekstrak daun kelor pada dosis $450 \mathrm{mg} / \mathrm{kgBB}$ dan pemberian suplemen vitamin dosis $5,4 \mathrm{ml} / \mathrm{kgBB}$ terhadap kadar hemoglobin pada tikus putih jantan.

Berdasarkan tabel 4 menunjukkan bahwa terdapat kadar hemoglobin pada tikus putih mengalami kenaikan pada kelompok KP2 yang memiliki rata-rata $17,4 \pm$ SD 4,6 dan $18,2 \pm$ SD 4,5 dengan hasil uji paired $t$ test $(p=0,014)$ lebih kecil dari 0,05 artinya terjadi perbedaan yang signifikan. Hal ini menunjukkan bahwa pemberian ekstrak daun kelor dengan dosis $450 \mathrm{mg} / \mathrm{kgBB}$ dapat memperbaiki kadar hemoglobin menjadi normal. Kelompok kontrol positif (KP)yang memiliki rata-rata $16,3 \pm$ SD 1,4 dan $17,2 \pm$ SD 1,7 dengan hasil uji paired $t$ test $(p=0,012)$ lebih kecil dari 0,05 artinya terjadi perbedaan kadar hemoglobin yang signifikan antara kelompok yang diberi perlakuan selama 14 hari. Hal ini menunjukkan bahwa pemberian suplemen vitamin dengan dosis $5,4 \mathrm{ml} / \mathrm{kgBb}$ dapat membantu memperbaiki kadar hemoglobin menjadi normal.

Kelompok Murni (KM) yang memiliki rata-rata $12,1 \pm$ SD 0,5 dan $11,2 \pm$ SD 1,3 dengan hasil uji paired $t$ test $(p=0,155)$ yaitu lebih besar dari 0,05 artinya tidak adanya perbedaan kadar hemoglobin, hal ini karena kelompok murni (KM) tidak diberikan perlakuan apapun, hanya diberikan pakan standar sehingga kadar hemoglobinnya tetap nomal. Kelompok KP1 yang memiliki rata-rata $13,6 \pm$ SD 3,5 dan 14,3 \pm SD 4,9 dengan hasil uji 
paired t-test $(p=0,329)$ yaitu lebih besar dari 0,05 artinya tidak adanya perbedaan kadar hemoglobin sebelum dan setelah diberikan ekstrak daun kelor, hal ini menunjukkan bahwa pada kelompok KP1 kadar hemoglobin cenderung pada kondisi anemia yang diberikan ekstrak daun kelor dosis 150 $\mathrm{mg} / \mathrm{kgBB}$, hal ini karena dosis yang diberikan tidak terlalu besar sehingga dapat menyebabkan terjadinya penurunan kadar hemoglobin.

Pada penelitian yang dilakukan Tinna (2018), daun kelor dapat dikonsumsi sebagai bahan pangan dan sayuran untuk dapat meningkatkan kadar hemoglobin dengan anemia karena adanya defesiensi zat besi. Anemia defesiensi zat besi disebut juga sebagai anemia gizi karena kekurangan zat gizi yang dapat berperan dalam pembentukkan hemoglobin. Zat besi disebut juga sebagai besi, protein, piridoksin (vitamin B6) yang berperan dalam pembentukkan hemoglobin, vitamin C juga dapat mempengaruhi absoprsi dan pelepasan besi dari transferin ke dalam jaringan tubuh.

Pada penelitian yang telah dilakukan oleh Suzana et al (2017), ekstrak daun kelor memiliki kandungan protein $27,33 \%$ dengan metode Kjeldahl. Total kandungan daun kelor yang terdapat dalam besi pada ekstrak daun kelor memiliki rata-rata 14,67 $\mathrm{mg} / 100 \mathrm{~g}$. Ekstrak daun kelor juga mengandung vitamin $C$ dengan nilai $759,05 \mathrm{mg} / 100 \mathrm{~g}$. Jika satu kapsul yang terdapat pada ekstrak daun kelor dengan jumlah $700 \mathrm{mg}$ kandungan pada kadar besi adalah 0,103 mg zat besi/ kapsul, vitamin C $5.313 \mathrm{mg} / \mathrm{kapsul} \mathrm{dan}$ protein 39,049 mg dalam satu kapsul.

Berdasarkan tabel 5 di atas diketahui bahwa analisis statistik hasil dari uji kruskal-wallis menunjukkan adanya selisih hb $(p=0,05)$ pada kelompok KM dengan kelompok KP1 $\mathrm{p}=0,020$, kelompok $\mathrm{Km}$ dengan kelompok KP2 $p=0,018$, kelompok $\mathrm{Km}$ dengan kelompok KP $p=0,009$, kelompok KP1 dengan kelompok KM $\mathrm{p}=0,020$, kelompok KP2 dengan kelompok KM $\mathrm{p}=0,018$, dan kelompok $K P$ dengan kelompok KM $p=0,009$. Hal ini menunjukkan bahwa adanya selisih perbedaan yang bermakna antara kelompok.

Penelitian oleh Rahmawati
(2017), bahwa penelitian yang dilakukan di balai penelitian rempah dan obat menunjukkan hasil bahwa I kg daun kelor memiliki kandungan $\mathrm{Fe}$ sebanyak 54,92 mg. Daun kelor imi sangat mudah ditemukkan dan mudah berkembang biak secara stek di tempat yang subur. Pada penelitian yang dilakukan Tinna (2018), daun kelor dapat dikonsumsi sebagai bahan pangan dan sayuran untuk dapat meningkatkan kadar hemoglobin dengan anemia karena adanya defesiensi zat besi. Anemia defesiensi zat besi disebut juga sebagai anemia gizi karena kekurangan zat gizi yang dapat berperan dalam pembentukkan hemoglobin. Zat besi disebut juga sebagai besi, protein, piridoksin (vitamin B6) yang berperan dalam pembentukkan hemoglobin, vitamin C juga dapat mempengaruhi absoprsi dan pelepasan besi dari transferin ke dalam jaringan tubuh.

Berdasarkan tabel 6 di atas diketahui bahwa Hasil analisis selanjutnya dilakukan dengan post hoc menggunakan Mann-Whitney menunjukan adanya perbedaan yang bermakna $(p<0,05)$ antara kelompok, didapatkan perbedaan bermakna $(p<0,05)$ pada kelompokKMdengan KP2 $(p=\quad 0,002)$ dan kelompok $\operatorname{KMdenganKP}(p=0,002)$ maka dapat dikatakan bahwa ada pengaruh pemberian ekstrak daun kelor pada dosis $450 \mathrm{mg} / \mathrm{kgBB}$ dan pemberian suplemen vitamin dosis $5,4 \mathrm{ml} / \mathrm{kgBB}$ terhadap kadar hemoglobin pada tikus putih jantan.

Berdasarkan penelitian yang dilakukan oleh Briawan (2016), bahwa pemberian tablet tambah darah masih menjadi salah satu upaya untuk mencegah terjadinya anemia. Selain itu juga dianjurkan untuk untuk memenuhi kebutuhan zat besi dari konsumsi makanan sumber zat besi darisumber protein hewani, protein nabati dan sumber vitamin $\mathrm{C}$ yaitu seperti daging merah, ikan, telur, sayuran hijau seperti daun kelor, bayam, kangkung. Analisis data yang telah dilakukan dalam penelitian ini menunjukkan bahwa 
terdapat peningkatan kadar hemoglobin pada tikus putih setelah diberikan ekstrak daun kelor yang terdapat dosis $450 \mathrm{mg} / \mathrm{kgBB}$ dan dosis $5,4 \mathrm{ml} / \mathrm{kgBB}$ pada suplemen vitamin. Supelem vitamin tersebut dapat mendukung eritropoesis melalui peningkatan poliferasi dalam darah. Peningkatan eritropoetin dalam darah akan tersirkulasi juga terdapat kandungan pembentuk sel darah merah seperti (zat besi, mangan, vitamin B12).

$$
\text { Penelitian yang dilakukan }
$$

Aminah, dkk (2015), daun kelor merupakan salah satu tanaman yang telah dinekal berabad-abad sebagai salah satu tanaman yang multiguna, padat akan nutrisi dan khasiat obat. Kandungan kelor memiliki senyawa alami yang lebih banyakberagam dibandingkan jenis tanaman lainnya. Menurut hasil penelitiannya, daun kelor mengandung vitamin $A$, vitamin $B$, vitamin $C$, kalsium, kalium, zat besi dan protein dalam jumlah yang sangat tinggi mudah dicerna oleh tubuh manusia. Tingginya kandungan zat besi (Fe) pada daun kelor kering ataupun dalam bentuk tepung memiliki nilai setara dengan 25 kali lebih tinggi dibandingkan bayam, sehingga daun kelor dapat dijadikan sebagai salah satu upaya alternatif untuk mencegah penanggulangan anemia.

Hasil penelitian yang dilakukan oleh Kurniawati, dkk (2019), yang menyatakan bahwa pemberian ekstrak daun kelor dapat menurunkan kadar Hemoglobin dan meningkatkan kadar hemoglobin dalam tubuh, pemberian antioksidan yang berasal dari ekstrak daun kelor (Moringa oleifera) dengan dosis $13 \mathrm{gr}$ dapat digunakan secara signifikan untuk meningkatkan kadar hemoglobin dan dosis 6,5 gr menurunkan hemoglobin pada tikus wistar jantan yang dilakukan selama 14 hari.Ekstrak daun kelor dapat mendukung eritropoesis melalui pengurangan sitokin pro-inflamasi dan meningkatkan poliferasi sel progenitor eritroid sehingga terjadi peningkatan kadar hemoglobin dan pencegahan akibat anemia dengan upaya menambahkan suplemen vitamin sebagai salah satu upaya untuk meningkatkan kadar hemoglobin akibat adanya kerusakan sel pada radikal bebas.

Radikal bebas memiliki dampak secara langsung ke berbagai penyakit seperti diabetes melitus, strike dan kanker. Antioksidan berperan penting dalam menghambat radikal bebas, sehingga dapat memberikan perlindungan bagi manusia terhadap infeksi dan penyakit degeneratif, antioksidan tersebut terdapat pada daun kelor yang memiliki khasiat obat yang sangat penting dalam mencegah terjadinya berbagai jenis penyakit lainnya dan dapat membantu meningkatkan kadar hemoglobin akibat rendahnya darah dalam tubuh (Krisnadi, 2015).

\section{KESIMPULAN}

Diketahui hasil penelitian menunjukan Kadar hemoglobin memiliki rerata $12,1 \pm$ SD 0,5 dan $11,2 \pm$ SD 1,3 pada tikus putih (Rattus norvegicus) galur Wistar jantan yang tidak diberikan ekstrak daun kelor dan suplemen vitamin.

Diketahui hasil penelitian menunjukan Kadar hemoglobin memiliki rerata $13,6 \pm$ SD 3,5 dan $14,3 \pm$ SD 4,9 pada tikus putih (Rattus norvegicus) galur Wistar jantan yang diberikan ekstrak daun kelor dosis 150 mg/kgBB.

Diketahui hasil penelitian menunjukan Kadar hemoglobin memiliki rerata $17,4 \pm$ SD4,6 dan 18,2 \pm SD 4,5 pada tikus putih (Rattus norvegicus) galur Wistar jantan yang diberikan ekstrak daun kelor dosis $450 \mathrm{mg} / \mathrm{kgBB}$.

Diketahui hasil penelitian menunjukan Kadar hemoglobin memiliki rerata 16,3 \pm SD 1,4 dan $17,2 \pm$ SD 1,7 pada tikus putih (Rattus norvegicus) galur Wistar jantan yang diberikan suplemen vitamin dosis $5,4 \mathrm{ml} / \mathrm{kgBB}$.

Diketahui hasil penelitian menunjukan terdapat pengaruh kadar hemoglobin pada tikus putih (Rattus norvegicus) galur Wistar jantan yang diberikan ekstrak daun kelor dosis 150 $\mathrm{mg} / \mathrm{kgBB}$ dan $450 \mathrm{mg} / \mathrm{kgBB}$.

Diketahui hasil penelitian menunjukan terdapat dosis efektif pada dosis $450 \mathrm{mg} / \mathrm{kgBB}$ terhadap kadar 
hemoglobin pada tikus putih (Rattus norvegicus) galur Wistar jantan.

\section{DAFTAR PUSTAKA}

Amalia, A. dan Tjiptaningrum, A. (2016). Diagnosis dan Tatalaksana Anemia Defisiensi Besi. Medical Journal of Lampung University 5(5): 166-169.

Aminah, S., Ramdhan, T., Yanis, M. (2015). Kandungan Nutrisi dan Sifat Fungsional Tanaman Kelor (Moringa oleifera). Buletin Pertanian Perkotaan 5(2): 35-44.

Briawan, D. (2016). Determinan Keberhasilan Program Suplementasi Zat Besi Pada Siswi Sekolah. Jurnal Gizi Klinik Indonesia 6(2).

Indriani, L., Zaddana, C., Nurdin, N.M., Sitinjak, J.S.M. (2019). Pengaruh Pemberian edukasi Gizi dan Kapsul Serbuk Daun Kelor (Moringa oleifera $L$ ) terhadap Kenaikan Kadar Hemoglobin Remaja Putri di Universitas Pakuan. Media Pharmaceutica Indonesiana 2(4).

Kementerian Kesehatan RI. (2013). Farmakope Herbal Indonesia. Jakarta: Kementrian Kesehatan Republik Indonesia.

Krisnadi, A.D. (2015). Kelor Super Nutrisi. Semarang: Pusat Informasi dan Pengembangan Tanaman Kelor Indonesia LSMMEPELING.

Kumalasari, D., Kameliawati, F., Mukhlis, H., \& Kristanti D.A. (2019). Pola Menstruasi dengan Kejadian Anemia pada Remaja. Wellness and Healthy Magazine 1(2): 187-192.

Kurniawati, I., Fitriyya, M., dan Wijayanti. (2019). Pengaruh Pemberian Tepung Kelor

Terhadap Peningkatan Kadar HB Dalam Darah Tikus. Jurnal IImiah Kesehatan 12(1). ISSN 19783167, E-ISSN 2580-135X.

Mursito, S., Lilies, B., Mawaddah, H. (2020). Ekstrak Daun Kelor (Moringa oleifera Lamk) dalam Menurunkan Kadar Glukosa Darah Pada Tikus (Rattus norvegicus). Journal Bionature 21(1).
Nugroho, R.A., (2018). Mengenal Mencit Sebagai Hewan Laboratorium. Samarinda: Mulawarman University Press: 76.

Rahmawati, M. (2017). Pengaruh Ekstrak Daun Kelor Terhadap Peningkatan Kadar hemoglobin Pada Ibu Hamil Trimester 2 dan 3 Di Puskesmas Semanau 1. [Naskah Publikasi]. Yogyakarta: Fakultas IImu Kesehatan Universitas Aisyah.

Setiawan, T., Susilaningsih, N., Saktini, F. (2018). Pengaruh Pemberian Ekstrak Daun Kelor (Moringa oleifera) Dosis Bertingkat Terhadap Gambaran Mikroskopis Gaster Tikus Wistar Jantan Yang Diinduksi Formalin. Jurnal Kedokteran Diponegoro 7(2): 1358-1368.

Suhada, R.I., Fitriani, A., dan Widiany, F.L (2019). Efektivitas Sayur Bayam Terhadap Perubahan Kadar Hemoglobin Remaja Putri Di SMP Klasan, Sleman, Yogyakarta. Jurnal Pangan dan Gizi 9(1): 1626.

Suzana, D., Suyatna, F.D., Azizahwati, Andrajati, R., Sari, S.P., Mun'im, A. (2017). Effect of Moringa oleifera Leaves Extract Againts Hematology and Blood Biochemical Value of Patients with Iron Deficiency Anemia. Journal of Young Pharmacists 9(1): 79-84.

Tinna, I. (2018). Pengaruh Pemberian Tepung Daun Kelor (Moringa oleifera Leaves) Terhadap Peningkatan Kadar Hemoglobin Eritrosit pada Ibu Hamil Anemia. [Tesis]. Makassar: Universitas Hasanuddin.

WHO. (2015). The Global Prevalence of Anemia. Geneva: World Health Organization

Widyastuti, D.A. (2013). Profil Darah Tikus Putih Wistar Pada Kondisi Subkronis Pemberian Natrium Nitrit. Jurnal Sain Veteriner 31(2): 208. ISSN:0126-0421

Winarno, F.G. (2018). Tanaman Kelor (Moringa oleifera) Nilai Gizi, Manfaat, dan Potensi Usaha. Jakarta: PT Gramedia Pustaka Utama. 